\title{
PENGARUH MODAL DAN TENAGA KERJA TERHADAP PRODUKSI INDUSTRI KERAJINAN KULIT DI KABUPATEN MERAUKE
}

\author{
Riza Fachrizal* \\ Staf Pengajar Jurusan Agribisnis FAPERTA UNMUS-Merauke, e-mail: -
}

\begin{abstract}
ABSTRAK
Kabupaten Merauke sebagai salah satu wilayah dari Provinsi Papua memiliki bermacam-macam subsektor industri kecil yang diharapkan kompetitif dan mampu menciptakan lapangan kerja bagi masyarakat. Salah satunya adalah industri kerajinan kulit yang keberadaannya diharapkan dapat berperan besar dalam peningkatan perekonomian daerah. Industri kerajinan kulit merupakan proses produksi yang secara teknis adalah hubungan antara faktor produksi dengan produksi, faktor produksi dengan faktor produksi, dan produksi dengan produksi. Peran industri kerajinan kulit dalam peningkatan pertumbuhan ekonomi daerah adalah melalui perluasan lapangan usaha dan kesempatan kerja. Kemampuan industri kerajinan kulit menyerap tenaga kerja dan menjadi pilihan usaha ditentukan oleh seberapa besar pengaruh faktor produksi modal dan tenaga kerja terhadap produksi. sehingga perlu dilakukan studi mengenai pengaruh faktor produksi modal dan tenaga kerja terhadap produksi pada industri kerajinan kulit di Kabupaten Merauke. Data yang diamati dalam penelitian ini adalah data time series. Menggunakan model estimasi regresi linier berganda dalam bentuk double log untuk mengetahui hubungan pengaruh dari variabel penelitian. Hasil regresi dari model estimasi menunjukkan bahwa koefisien regresi variabel modal 0,573 dan koefisien regresi variabel tenaga kerja 1,152 secara statistik signifikan pada a $=5 \%$. Variabel modal dan variabel tenaga kerja berpengaruh positif terhadap produksi pada industri kerajinan kulit di Kabupaten Merauke. Hasil penelitian menyatakan bahwa modal dan tenaga kerja mempunyai pengaruh yang positif terhadap produksi, artinya apabila salah satu faktor produksi tersebut meningkat maka akan meningkatkan produksi pada industri kerajinan kulit di Kabupaten Merauke.
\end{abstract}

Kata Kunci: Industri Kerajinan Kulit, Produksi, Modal dan Tenaga Kerja.

I. PENDAHULUAN

1.1. Latar Belakang

Pembangunan nasional merupakan usaha peningkatan kualitas manusia dan masyarakat Indonesia yang dilakukan secara berkelanjutan, berlandaskan kemampuan nasional dengan memanfaatkan kemajuan ilmu pengetahuan dan teknologi serta memperhatikan perkembangan global. Salah satu usaha yang dilakukan oleh bangsa Indonesia yaitu mengusahakan percepatan pertumbuhan ekonomi negara yang bertujuan mencapai kemakmuran dan kesejahteraan bagi seluruh masyarakat Indonesia.
Pertumbuhan dan perkembangan ekonomi secara sektoral telah mengalami pergeseran. Sektor pertanian yang awalnya merupakan sektor yang mempunyai kontribusi besar terhadap perekonomian negara mulai beralih pada sektor industri seiring dengan perkembangan teknologi dan masuknya modal asing ke Indonesia. Jadi proses pembangunan ekonomi mengalami perubahan dimana kesempatan kerja di sektor pertanian beralih ke arah sektor industri, hal ini disebabkan karena makin sempitnya luas lahan pertanian yang menyebabkan menurunnya pendapatan petani di pedesaan. 
Pemerintah mengambil kebijakan dipilihnya sektor industri dalam pembangunan ekonomi Indonesia guna menghadapi semakin banyaknya angkatan tenaga kerja sehingga tercapai keseimbangan antara pertumbuhan ekonomi dengan pertumbuhan penduduk.

Pembangunan daerah merupakan bagian integral dari pembangunan nasional yang dilaksanakan berdasarkan prinsip otonomi daerah dengan memberikan kesempatan bagi daerah untuk meningkatkan kesejahteraan, daya guna dan hasil guna penyelenggaraan pemerintahan, serta pelayanan kepada masyarakat. Keberhasilan pertumbuhan ekonomi daerah dapat di ukur dari pertumbuhan Produk Domestik Regional Bruto (PDRB). Dalam usaha percepatan pembangunan ekonomi daerah, industrialisasi merupakan salah satu strategi yang dilakukan oleh pemerintah.

Industrialisasi memiliki peran strategis untuk mendukung pertumbuhan ekonomi secara berkelanjutan dan meningkatkan produksi masyarakat melalui perluasan lapangan usaha dan kesempatan kerja serta mendorong pembangunan daerah dan pengentasan kemiskinan. Pertumbuhan ekonomi akan meningkatkan penyerapan tenaga kerja dengan asumsi terjadi peningkatan investasi.

Pembangunan sektor industri akan tumbuh baik jika tersedia investasi dalam kapasitas yang memadai, sehingga mampu menyerap angkatan kerja di samping menyerap kelebihan tenaga kerja disektor pertanian. Sejalan dengan tujuan pembangunan yaitu pemerataan pendapatan melalui perluasan kesempatan kerja, maka eksistensi sub sektor industri kecil pantas dan harus mendapatkan perhatian yang lebih besar dan diharapkan mampu meningkatkan skala usaha yang disertai dengan semakin berkembangnya kemampuan dan kemandirian berusaha.

Berdasarkan jumlah tenaga kerja di sektor industri di bagi menjadi empat kelompok yaitu industri besar, industri sedang, industri kecil, dan industri rumah tangga. Industri besar adalah yang memiliki 100 atau lebih tenaga kerja, industri sedang yang memiliki 20 - 99 tenaga kerja, industri kecil yang memiliki 5 - 19 tenaga kerja, dan industri rumah tangga yaitu industri yang mengerjakan kurang dari lima tenaga kerja (BPS, 2010).

Dalam teori ekonomi makro, dari sisi pengeluaran, pendapatan regional bruto adalah penjumlahan dari berbagai variabel termasuk didalamnya adalah investasi. Ada beberapa hal yang sebenarnya berpengaruh dalam soal investasi ini. Investasi sendiri dipengaruhi oleh investasi asing dan domestik. Investasi yang terjadi di daerah terdiri dari investasi pemerintah dan investasi swasta dapat berasal dari investasi pemerintah dan investasi swasta. Investasi dari sektor swasta dapat berasal dari dalam negeri maupun luar negeri (asing). Investasi pemerintah dilakukan guna menyediakan barang publik. Besarnya investasi pemerintah dapat dihitung dari selisih antara total anggaran pemerintah dengan belanja rutinnya.

Selain investasi, maka tenaga kerja merupakan suatu faktor yang mempengaruhi output suatu daerah. Angkatan kerja yang besar akan terbentuk dari jumlah penduduk yang besar. Namun pertumbuhan penduduk dikhawatirkan akan menimbulkan efek yang buruk terhadap pertumbuhan ekonomi. Menurut Rustiono (2008) pertumbuhan penduduk yang cepat mendorong timbulnya masalah keterbelakangan dan membuat prospek pembangunan menjadi semakin jauh. Selanjutnya dikatakan bahwa masalah kependudukan yang timbul bukan karena banyaknya jumlah anggota keluarga, melainkan karena mereka terkonsentrasi pada daerah perkotaan saja sebagai akibat dari cepatnya laju migrasi dari desa ke kota. Namun demikian jumlah penduduk yang cukup dengan tingkat pendidikan yang tinggi dan memiliki skill akan mampu mendorong laju pertumbuhan ekonomi. Dari jumlah penduduk usia produktif yang besar maka akan mampu meningkatkan jumlah angkatan kerja yang tersedia dan pada akhirnya akan mampu meningkatkan produksi output di suatu daerah.

Sumber daya produksi yang berasal dari sektor pertanian dan kehutanan yang terdiri atas hasil pertanian tanaman pangan, perikanan, perkebunan dan hasil hutan yang banyak menghasilkan bahan mentah yang digunakan sebagai bahan baku/bahan penolong bagi sektor industri tersedia dengan 
baik, sehingga pembangunan industri mampu mewujudkan struktur ekonomi yang semakin baik serta menciptakan keseimbangan antara sektor industri dengan sektor yang lainnya.

Pembangunan di Provinsi Papua yang memiliki luas wilayah 16,70 persen dari luas Indonesia dengan 28 kabupaten dan 1 kota membutuhkan usaha keras bersama antara pemerintah dan masyarakat. Pencapaian hasil pembangunan yang dilaksanakan secara menyeluruh dan berkesinambungan telah dirasakan serta meningkatkan perekonomian masyarakat di Papua. Namun di sisi lain berbagai kendala masih dihadapi oleh penentu kebijakan di tingkat provinsi maupun kabupaten/kota dalam memaksimalkan potensi sumber daya manusia dan sumber modal yang merupakan faktor penting dalam usaha percepatan pembangunan daerah.

Kabupaten Merauke sebagai salah satu wilayah dari Provinsi Papua secara umum memiliki sektor industri yang didominasi oleh subsektor industri kecil. Pengembangan subsektor industri kecil akan membantu mengatasi masalah pengangguran mengingat teknologi yang digunakan adalah teknologi padat karya sehingga bisa memperbesar lapangan kerja dan kesempatan usaha, yang pada gilirannya mendorong pembangunan daerah dan kawasan pedesaan. Sektor industri di Kabupaten Merauke memiliki peranan yang cukup menunjang perekonomian daerah meskipun belum mampu menjadi sektor unggulan dalam perekonomian secara keseluruhan.

Di Kabupaten Merauke terdapat bermacam-macam subsektor industri kecil yang diharapkan kompetitif dan mampu menciptakan lapangan kerja bagi masyarakat. Salah satunya adalah industri kerajinan kulit. Keberadaan industri kerajinan kulit diharapkan memiliki peran besar dalam peningkatan perekonomian daerah. Berdasarkan latar belakang di atas timbul pertanyaan apakah industri kerajinan kulit mampu menjadi industri yang dapat memberikan kontribusi dalam meningkatkan perekonomian daerah. Maka perlu dilakukan penelitian mengenai pengaruh faktor produksi modal dan tenaga kerja terhadap produksi pada industri kerajinan kulit di Kabupaten Merauke.

\subsection{Tujuan Penelitian}

Penelitian ini bertujuan untuk :

1. Untuk mengetahui apakah modal dan tenaga kerja mempunyai pengaruh terhadap produksi pada industri kerajinan kulit di Kabupaten Merauke.

2. Untuk mengetahui sejauh mana pengaruh modal dan tenaga kerja terhadap produksi pada industri kerajinan kulit di Kabupaten Merauke.

\section{METODE PENELITIAN}

\subsection{Lokasi Penelitian}

Penelitian ini mengambil lokasi di Kabupaten Merauke, karena di daerah ini memiliki nilai investasi pada industri terbesar di Papua dan berbagai industri kerajinan kulit yang telah berkembang dengan baik (BPS Papua, 2011).

\subsection{Jenis dan Sumber Data}

Penelitian ini melakukan analisis pengaruh modal dan tenaga kerja terhadap produksi pada industri kerajinan kulit formal di Kabupaten Merauke.

Data yang dipergunakan dalam penelitian ini adalah data sekunder dari Laporan Tahunan Dinas Perindustrian dan Perdagangan Kabupaten Merauke yang meliputi:

1. Produksi yang dihasilkan tiap unit usaha

2. Modal Kerja tiap unit usaha

3. Jumlah tenaga kerja tiap unit usaha

4. Data penunjang lainnya didapatkan dari data publikasi Biro Pusat Statistik (BPS) Kabupaten Merauke yaitu Merauke Dalam Angka.

\subsection{Metode Pengumpulan Data}

Data yang dikumpulkan bersifat kuantitatif dan menggunakan metode dokumentasi yaitu mengumpulkan data yang berkaitan dengan masalah penelitian dari instansi terkait. Adapun data tersebut adalah data jumlah unit industri, jumlah produksi, jumlah modal dan jumlah tenaga kerja dalam industri kerajinan kulit formal.

\subsection{Metode Analisis}

Alat yang digunakan untuk menganalisis pengaruh modal dan tenaga kerja terhadap 
produksi pada industri kerajinan kulit terhadap jumlah produksi.

$$
\mathrm{Q}=f(\mathrm{~K}, \mathrm{~L})
$$

Model tersebut dapat ditransformasikan

kedalam persamaan logaritma:

$$
\operatorname{Ln} Q=\beta_{0}+\beta_{1} \operatorname{Ln} K+\beta_{2} \operatorname{Ln} L+\mu
$$

Dimana :

$$
\begin{array}{ll}
\mathrm{Q} & =\text { Produksi } \\
\beta_{0} & =\text { Intersep } \\
\beta_{1}, \beta_{2}, \beta_{3} & =\text { Koefisien regresi } \\
\mathrm{K} & =\text { Modal } \\
\mathrm{L} & =\text { Tenaga Kerja } \\
\mu & =\text { Standar Error }
\end{array}
$$

\section{Uji Model}

Untuk mengetahui model regresi ini layak atau tidak digunakan, maka dilakukan pengujian model terhadap asumsi klasik yang meliputi uji multikolinearitas, heteroskedastisitas, dan autokorelasi.

\section{Uji Multikolinearitas}

ji Multikolinearitas bertujuan untuk menguji apakah model regresi ditemukan adanya korelasi antar variabel bebas (independen). Untuk mendeteksi ada atau tidaknya multikolinearitas didalam model regresi dapat dilihat dari nilai $R^{2}$ yang dihasilkan oleh suatu estimasi model regresi empiris sangat tinggi, antar variabel bebas terdapat korelasi yang cukup tinggi (umumnya diatas 0,90), nilai toleransi dan nilai Varian Information Faktor (VIF). Nilai toleransi mengukur variabilitas variabel bebas yang terpilih yang tidak dapat dijelaskan oleh variabel bebas lainnya. Jadi nilai toleransi yang rendah sama dengan nilai VIF tinggi (VIF $=1 /$ toleransi). Apabila nilai VIF lebih besar dari 10 menunjukkan bahwa hasil estimasi model regresi terdapat indikasi adanya multikolinearitas yang serius.

2. Uji Heteroskedastisitas

Uji Heteroskedastisitas bertujuan menguji apakah dalam suatu model regresi terdapat ketidaksamaan variansi dari residual satu pengamatan ke pengamatan yang lain. jika varian dari residual satu pengamatan ke pengamatan yang lain tetap maka disebut homoskadastisitas dan jika berbeda disebut heteroskadastisitas. Dalam penelitian ini uji heteroskadisitas dilihat dengan melihat grafik plot antara nilai prediksi variabel terikat dengan residualnya. Deteksi ada atau tidaknya heteroskadastisitas dapat dilakukan dengan melihat ada tidaknya pola tertentu pada grafik scatterplot antara prediksi variabel terikat dengan residualnya, jika ada pola tertentu maka mengindikasikan telah terjadi heteroskedastisitas.

3. Uji Autokorelasi

Uji Autokorelasi bertujuan untuk menguji apakah dalam suatu model regresi terdapat korelasi antara kesalahan pengganggu pada periode sebelumnya. Untuk mendeteksi ada tidaknya autokorelasi dapat dilakukan dengan Uji Durbin - Watson (DW test yaitu membandingkan antara nilai DW statistik dengan nilai:

- Jika hipotesis Ho adalah bahwa tidak ada serial korelasi positif, maka jika :

$\mathrm{d}<\mathrm{dL}$ : menolak Ho

d $>$ dU : tidak menolak Ho

$\mathrm{dL}<\mathrm{d}<\mathrm{dU}$ : pengujian tidak meyakinkan.

- Jika hipotesis nol Ho adalah bahwa tidak ada serial korelasi negatif, maka jika :

d > 4 - dL : menolak Ho

$\mathrm{d}<4-\mathrm{dL}$ : tidak menolak Ho

$4-\mathrm{dU}<\mathrm{d}<4-\mathrm{dU}$ : pengujian tidak meyakinkan.

- Jika Ho adalah dua ujung, yaitu bahwa tidak ada serial autokorelasi baik positif maupun negatif, maka jika :

$\mathrm{d}<\mathrm{dL}$ : menolak Ho

d $>4$ - dL : menolak Ho

$\mathrm{dU}<\mathrm{d}<4-\mathrm{dU}$ : tidak menolak Ho

$\mathrm{dL}<\mathrm{d}<\mathrm{dU}$ : pengujian tidak meyakinkan.

$4-\mathrm{dU}<\mathrm{d}<4-\mathrm{dL}$ : pengujian tidak meyakinkan.

\section{$\underline{\text { Uii Hipotesis }}$}

1. Uji t (Parsial)

Pengujian uji $t$ digunakan untuk mengetahui seberapa jauh hubungan satu variabel bebas secara signifikan individual dalam menerangkan variabel terikatnya (Algifari, 2009). Nilai $t$ diformulasikan dengan rumus sebagai berikut:

$$
t_{\text {hitung }}=\frac{\beta \mathbf{t}}{\operatorname{Se} \beta \mathbf{t}}
$$

Dimana:

$$
\beta \mathrm{t}=\text { koefisien regresi }
$$


Se $\beta \mathbf{t} \quad=$ penyimpangan baku.

Alat ini untuk mengetahui pengaruh masing-masing variabel bebas terhadap variabel tidak bebas. Hipotesis yang digunakan untuk uji $t$ dapat dirumuskan sebagai berikut :

Ho : $\beta_{1} \leq 0$ tidak ada pengaruh terhadap produksi

Ha : $\beta_{1}>0$ ada pengaruh terhadap produksi

Bila nilai $\mathbf{t}$ hitung $<\mathbf{t}$ tabel maka Ho diterima dan bila nilai $t$ hitung $>\mathbf{t}$ tabel maka Ho ditolak yang. berarti bahwa variabel yang bersangkutan ada pengaruh yang signifikan.

\section{Uji F (Uji Signifikansi Simultan)}

Untuk menguji signifikansi persamaan

regresi adalah untuk mengetahui pengarul?. modal dan tenaga kerja terhadap produksà. dapat dilakukan dengan uji $F$ dengan formulasi sebagai berikut :

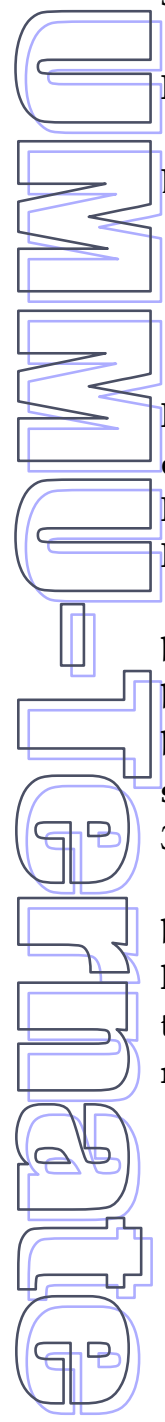
$\mathrm{F}=$

$$
\mathbf{R}^{2} /(\mathbf{k}-\mathbf{1})
$$

$$
\left(1-R^{2}\right) /(n-k)
$$

Dimana :

$$
\mathbf{R}^{2}=\text { Koefisien determinan }
$$

n = jumlah responden

k = jumlah variabel independen termasuk konstanta.

Hipotesis yang digunakan untuk uji F, dirumuskan sebagai berikut:

Ho : $\beta_{1}=\beta_{2}=\ldots=\beta n=0$ (tidak ada pengaruh)

Ha : $\beta_{1} \# \beta_{2} \# \ldots . .=\beta n \# 0$ (ada pengaruh dan

$$
\text { signifikan) }
$$

bila nilai $F_{\text {hitung }}<\mathrm{F}_{\text {tabel, }}$ maka Ho diterima dan

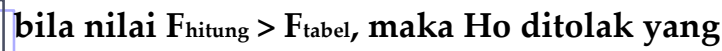
berarti bahwa variabel bebas ada pengaruh secara bersama-sama.

3. $\mathbf{R}^{2}$ (Koefisien Determinasi)

Pengujian koefisien determinasi ini bertujuan untuk mengetahui seberapa jauh hubungan variabel-variabel bebas (X) terhadap variabel terikat (Y). Nilai $R^{2}$ mempunyai range antara $0-1$. Jika nilai $R^{2}$ mendekati 0 (nol) maka dimaksudkan antara variabel bebas dan variabel tidak bebas tidak ada keterkaitan tetapi jika nilai $\mathbf{R}^{2}$ mendekati 1 maka dimaksudkan antara variabel bebas dan variabel tidak bebas ada keterkaitan atau dengan kata lain hasil estimasi akan semakin mendekati sebenarnya.

\subsection{Definisi Operasional}

Variabel Dependen (Y) produksi pada industri kerajinan kulit di Kabupaten Merauke (dalam satuan rupiah). Produksi merupakan nilai output yang dihasilkan oleh industri kerajinan kulit dalam periode waktu produksi tertentu.

Variabel Independen ( $X$ )

Modal ( $\left.X_{1}\right)$ adalah modal kerja yang merupakan keseluruhan biaya yang dikeluarkan dalam proses produksi pada industri kerajinan kulit di Kabupaten Merauke yang habis dalam periode waktu produksi tertentu. Moda14kerja tersebut diperoleh dengan menjumlahkan keseluruhan biaya yang digunakan untuk pembelian bahan baku produksi dan modal yang diinvestasikan pada proses produksi yang dihitung dalam satuan Rupiah (Rp) per tahun. Tenaga Kerja $\left(X_{2}\right)$ adalah semua orang yang bekerja pada industri kerajinan kulit di Kabupaten Merauke, dan dinyatakan dalam satuan orang per tahun.

\section{HASIL DAN PEMBAHASAN}

\subsection{Hasil Penelitian}

Hasil regresi terhadap faktor-faktor yang mempengaruhi produksi pada industri kerajinan kulit di Kabupaten Merauke disajikan dalam bentuk double log. Penyajian bentuk fungsi estimasi model tersebut mampu menggambarkan kondisi riil yang cukup baik. Ringkasan hasil regresi disajikan dalam tabel

\begin{tabular}{|c|c|c|c|c|}
\hline Model & Konstanta & Ln K & $\operatorname{Ln} \mathrm{L}$ & Sig \\
\hline Koefisien & 2.444 & 0.573 & 1.152 & $0.023 a$ \\
\hline thitung & 0.290 & 0.779 & $1.914^{*}$ & \\
\hline Fratio & 8.892 & & & \\
\hline $\mathbf{R}^{2}$ & 0.781 & & & \\
\hline
\end{tabular}
berikut:

Tabel 1. Ringkasan Hasil Regresi Faktor-Faktor Yang Mempengaruhi Produksi pada Industri Kerajinan Kulit Di Kabupaten Merauke Dalam Bentuk Double Log

Sumber: Lampiran 1 (data diolah)

* Signifikan pada $\alpha=10 \%$ 
Dari Tabel 1, dapat diketahui bahwa variabel tenaga kerja merupakan variabel yang berpengaruh secara signifikan terhadap produksi pada industri kerajinan kulit di Kabupaten Merauke.

Dari hasil analisis regresi pada tabel 5.1, maka dapat dilakukan uji apriori teori, uji statistik dan uji ekonometrika. Uji apriori dimaksudkan untuk mengetahui apakah arah hubungan antara variabel bebas dengan variabel terikat sudah sesuai dengan teori atau tidak. Uji statistik dimaksudkan untuk mengetahui apakah pengaruh variabel bebas terhadap variabel terikat signifikan secara statistik. Uji ekonometrika dimaksudkan untuk memastikan model estimasi yang digunakan merupakan penaksir linier terbaik yang tidak bias (BLUE).

1. Hasil uji apriori teori

Dalam teori produksi arah hubungan/pengaruh modal terhadap produksi adalah positif dan arah hubungan/pengaruh tenaga kerja terhadap produksi adalah positif. Dari tanda koefisien variabel bebas hasil regresi pada tabel 5.1 dapat diketahui arah hubungan/pengaruh variabel bebas yaitu modal dan tenaga kerja pada industri kerajinan kulit terhadap variabel terikat yaitu produksi. Arah pengaruh variabel modal terhadap produksi pada industri kerajinan kulit sesuai dengan asumsi teori yaitu positif, artinya apabila modal meningkat maka produksi akan meningkat dan sebaliknya. Arah pengaruh variabel tenaga kerja terhadap produksi pada industri kerajinan kulit sesuai dengan asumsi teori yaitu positif artinya apabila tenaga kerja meningkat maka produksi akan meningkat dan sebaliknya.

Tabel 2 Ringkasan Hasil Uji Multikolinieritas

\begin{tabular}{lccc} 
& \multirow{2}{*}{ Variabel } & \multicolumn{2}{c}{ Collinearity Statistics } \\
\cline { 2 - 3 } & & Tolerance & VIF \\
\hline Ln K & 0.373 & 2.683 \\
Ln L & 0.373 & 2.683
\end{tabular}

Sumber: Lampiran 2 (data diolah)

Dari tabel 2 terlihat bahwa nilai VIF untuk variabel bebas modal dan tenaga kerja di

\section{Hasil uji statistik}

Dari hasil regresi pada industri kerajinan kulit diperoleh bahwa variabel modal memiliki nilai thitung $(0,779)$ dan variabel tenaga kerja memiliki nilai thitung $(1,914)$. Hal ini berarti bahwa variabel tenaga kerja berpengaruh secara statistik terhadap produksi pada industri kerajinan kulit karena nilai thitung $>$ nilai tabel (1,476). Untuk variabel bebas lainnya yaitu modal tidak signifikan mempengaruhi produksi pada industri kerajinan kulit.

Secara bersama-sama variabel bebas (variabel modal dan variabel tenaga kerja) signifikan mempengaruhi variasi variabel terikat (produksi), karena nilai Fhitung $(8,892)$ yang diperoleh lebih besar dari nilai $F_{\text {tabel }}(5,79)$ dengan $\alpha=0,05, n=8$ dan $k=3$. Dengan demikian variabel bebas pada model estimasi secara bersama-sama dapat menjelaskan perubahan variasi variabel terikat.

Nilai koefisien determinasi $\left(\mathbf{R}^{2}\right)$ yang diperoleh cukup tinggi yakni 0,781. Hal ini berarti bahwa $78,1 \%$ variasi variabel terikat pada industri kerajinan kulit dapat dijelaskan oleh variabel bebas yang dimasukkan dalam model estimasi, sedangkan sisanya yaitu $21,9 \%$ dijelaskan oleh variabel lain yang tidak termasuk dalam model.

Nilai $\rho$-value $=0,023$. Dalam pengujian ini menggunakan $\alpha=5 \% \quad(\rho$-value $<0,05)$ maka secara statistik dapat dibuktikan bahwa variabel bebas pada industri kerajinan kulit berpengaruh terhadap variabel terikat.

3. Hasil uji ekonometrik

Uji penyimpangan asumsi klasik terdiri dari uji multikolinieritas autokorelasi dan heteroskedastisitas. Hasil uji multikolinieritas pada model estimasi dapat dilihat pada tabel berikut. dibawah angka 10, demikian pula dengan nilai toleransi mendekati 1 maka dapat disimpulkan 


bahwa kedua variabel penjelas yang
dimasukkan dalam model estimasi tidak
terdapat hubungan linier sempurna atau
dengan kata lain model empirik bebas dari
pengaruh multikolinieritas.
Uji autokorelasi disajikan dalam tabel

Berdasarkan Tabel 3 maka dapat disimpulkan bahwa model empirik yang digunakan bebas dari masalah autokorelasi.
Hal ini ditunjukkan dengan nilai DurbinWatsonhitung $(1,258)$ berada dalam wilayah yang tidak ada pengaruh autokorelasi.

Ringkasan hasil uji Heteroskedastisitas disajikan dalam bentuk gambar scatterplot berikut dapat dilihat pada Gambar 1 .

Dari gambar grafik scatterplot diatas tampak bahwa titik-titik menyebar dan tidak membentuk pola tertentu. Dengan demikian dapat disimpulkan bahwa tidak terjadi heteroskedastisitas.

Dari keseluruhan uji penyimpangan asumsi klasik yang telah dilakukan, model empirik bebas dari penyimpangan asumsi klasik. Dengan demikian model multiple regression yang digunakan dalam penelitian untuk estimasi pengaruh modal dan tenaga kerja terhadap produksi dari industri kerajinan kulit dapat menjadi estimator linier terbaik yang tidak bias (BLUE).

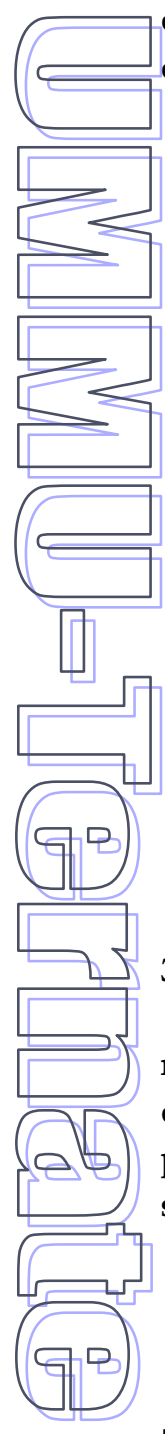

Scatterplot

Dependent Variable: LnQ

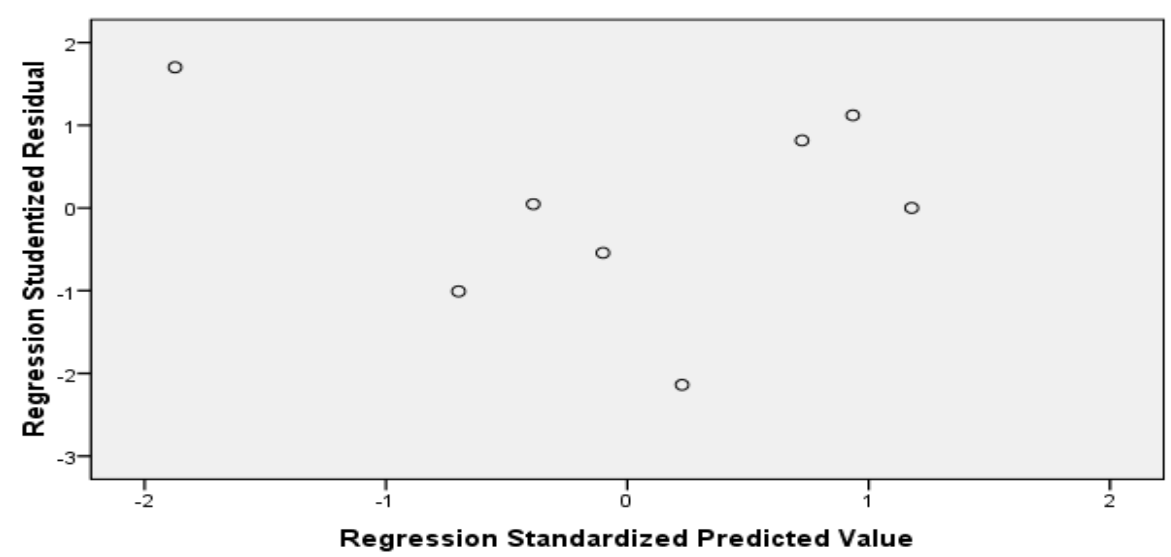

Gambar 1. Grafik Industri Kerajinan Kulit

\subsection{Pembahasan}

Dari hasil persamaan regresi diperoleh nilai koefisien dari variabel bebas yang dimasukkan ke dalam model estimasi. Model persamaan regresi yang digunakan adalah sebagai berikut :

$$
\operatorname{Ln} Q=2.444+0.573 \operatorname{Ln} K+1.152 \operatorname{Ln} L^{*}
$$

Dari model di atas sebagai variabel terikat adalah produksi (LnQ), sedangkan variabel bebas adalah modal (LnK) dan tenaga kerja (LnL). Arah pengaruh variabel bebas modal terhadap variabel terikat adalah positif dan terlihat pada model bahwa semakin meningkat modal (ceteris paribus), maka produksi semakin meningkat dan besarnya pengaruh peningkatan modal dapat dijelaskan oleh nilai koefisien regresi. Artinya bahwa apabila modal meningkat sebesar $1 \%$ (ceteris paribus), maka produksi akan (beh)ingkat sebesar $0,573 \%$. Arah pengaruh variabel bebas tenaga kerja terhadap variabel terikat adalah positif yang berarti bahwa semakin meningkat tenaga kerja (ceteris paribus), maka produksi semakin meningkat dan besarnya pengaruh 
peningkatan tenaga kerja dapat dijelaskan oleh nilai koefisien regresi. Artinya bahwa apabila tenaga kerja meningkat sebesar $1 \%$ (ceteris paribus), maka produksi akan meningkat sebesar $1,153 \%$.

Sadono Sukirno (2005) menggabungkan bagaimana tingkat produksi akan mengalami perubahan apabila faktor produksi yaitu tenaga kerja, terus menerus ditambah tetapi faktor-faktor produksi lainnya dianggap tetap jumlahnya. Dalam analisis diatas terdapat dua jenis faktor produksi yang dapat diubah jumlahnya, yakni tenaga kerja dan modal, kedua faktor yang dapat berubah ini dapat dipertukarkan penggunaannya. Apabila jumlah tenaga kerja dan besarnya modal diketahui, maka analisis tentang bagaimana perusahaan akan meminimumkan biaya dalam usahanya untuk mencapai suatu tingkatan produksi tertentu dapat diketahui dengan kurva produksi sama, yang menggambarkan gabungan tenaga kerja dan modal yang akan menghasilkan satu tingkat produksi tertentu.

Secara teoritis peningkatan tenaga kerja yang menyebabkan peningkatan produksi menunjukkan industri tersebut bersifat padat karya, dimana pengusaha dalam melakukan proses produksi akan menggunakan input tenaga kerja yang lebih banyak dibandingkan dengan penggunaan input mesin. Lebih jauh dapat dijelaskan bahwa setiap kali pengusaha industri kerajinan kulit melakukan ekspansi usahanya dengan meningkatkan modal kerja maka produksi dengan sendirinya akan meningkat. Hal ini menunjukkan bahwa hubungan antara input modal dengan input tenaga kerja pada industri kerajinan kulit di Kabupaten Merauke mempunyai hubungan yang bersifat substitusi.

Berdasarkan hasil analisis dan pembahasan di atas, maka dapat disimpulkan bahwa variabel modal dan tenaga kerja berpengaruh terhadap produksi pada industri kerajinan kulit di Kabupaten Merauke. Hal ini terlihat dari hasil regresi yang dilakukan ternyata secara bersama-sama variabel modal dan tenaga kerja signifikan berpengaruh terhadap variasi variabel terikat (produksi), dengan nilai Fhitung $(8,892)$ yang diperoleh lebih besar dari nilai $F_{\text {tabel }}(5,79)$ pada tingkat kepercayaan $95 \%$.
Dalam teori ekonomi asumsi dasar mengenai sifat dasar fungsi produksi yaitu fungsi produksi dari semua produksi di mana semua produsen dianggap tunduk pada suatu hukum yang disebut hukum tambahan hasil yang semakin berkurang (The Law Of Diminishing Return). Hukum ini mengatakan bila satu macam input ditambah penggunaannya sedang input-input yang lain tetap, maka tambahan output yang dihasilkan dari setiap tambahan satu unit input yang ditambahkan tadi mula-mula meningkat tetapi kemudian seterusnya menurun bila input tersebut terus ditambah. Hasil regresi faktor produksi modal dan tenaga kerja berpengaruh signifikan terhadap produksi menunjukkan bahwa industri kerajinan kulit di Kabupaten Merauke berada pada daerah produksi yang ekonomis.

\section{PENUTUP}

\subsection{Kesimpulan}

Berdasarkan hasil analisis dan pembahasan, maka dapat disajikan kesimpulan hasil penelitian sebagai berikut :

1. Variabel modal dan tenaga kerja secara bersama-sama signifikan berpengaruh terhadap variasi variabel terikat (produksi) pada industri kerajinan kulit di Kabupaten Merauke, dengan nilaiFhitung $(8,892)$ yang diperoleh lebih besar dari nilaiF tabel $(5,79)$ pada tingkat kepercayaan $95 \%$. Secara parsial variabel tenaga kerja berpengaruh signifikan terhadap produksi pada industri kerajinan kulit di Kabupaten Merauke dengan nilaithitung $(1,914)$ lebih besar dari nilait table $(1,476)$. Arah hubungan pengaruh dari variabel modal terhadap produksi pada industri kerajinan kulit di Kabupaten Merauke adalah positif, yang artinya bahwa apabila modal meningkat maka produksi akan meningkat dan sebaliknya. Arah hubungan pengaruh variabel tenaga kerja terhadap produksi pada industri kerajinan kulit di Kabupaten Merauke adalah positif artinya apabila tenaga kerja meningkat maka produksi akan meningkat dan sebaliknya. Setiap terjadi perubahan input produksi baik itu modal atau pun tenaga kerja berpengaruh terhadap produksi pada 
industri kerajinan kulit di Kabupaten Merauke.

2. Besarnya pengaruh variabel bebas terhadap variabel terikat dapat dijelaskan dengan melihat nilai koefisien regresi dari masingmasing variabel bebas. Nilai koefisien variabel modal adalah (0,573). Artinya bahwa apabila modal meningkat sebesar $1 \%$ (ceteris paribus), maka produksi pada industri kerajinan kulit di Kabupaten Merauke akan meningkat sebesar $0,57 \%$. Nilai koefisien variabel tenaga kerja adalah $(1,152)$. Artinya bahwa apabila tenaga kerja bertambah sebesar $1 \%$ (ceteris paribus), maka produksi pada industri kerajinan kulit di Kabupaten Merauke akan meningkat sebesar 1,15\%. Hal ini menunjukkan bahwa faktor produksi modal dan tenaga kerja sangat berpengaruh terhadap keberlangsungan proses produksi pada industri kerajinan kulit di Kabupaten Merauke.

\subsection{Saran}

1. Jika Pemerintah Daerah Kabupaten Merauke sebagai pelaksana dan penanggungjawab dalam proses pembangunan di daerah ingin mempercepat pertumbuhan ekonomi daerah maka dapat mempertimbangkan untuk mendorong perkembangan subsektor industri khususnya industri kecil yang salah satunya adalah industri kerajinan kulit yang berada di kabupaten tersebut. Subsektor industri kecil mampu bertahan dalam kondisi perekonomian dalam keadaan inflasi sekaligus mampu mengurangi jumlah angka pengangguran dengan menyediakan lapangan kerja serta berperan dalam meningkatkan perekonomian daerah.

2. Studi ini baru hanya merupakan langkah awal untuk mengetahui faktor-faktor produksi pada subsektor industri kecil khususnya industri kerajinan kulit yang mempengaruhi produksi, masih diperlukan penyempurnaan untuk dapat menjelaskan secara tepat faktor-faktor yang mempengaruhi mempengaruhi produksi pada industri kerajinan kulit dengan menggunakan variabel yang lebih representatif. Bagi pengusaha industri kerajinan kulit di Kabupaten Merauke yang akan meningkatkan produksinya dapat diusahakan melalui penambahan modal kerja atau pun tenaga kerja dengan memperhatikan sifat dasar fungsi produksi untuk memastikan bahwa usahanya berada pada daerah produksi yang ekonomis.

\section{DAFTAR PUSTAKA}

Ali Muhamad, 2004, Peranan Industri Kecil Dalam Penyerapan Tenaga Kerja Di Kabupaten Lombok Timur, 1991-2003, Tesis Tidak Dipublikasikan, UGM, Yogyakarta.

Algifari, 2009. Analisis Regresi Teori, Kasus dan Solusi, BPFE, Yogyakarta.

Badan Pusat Statistik Provinsi Papua, Papua Dalam Angka 2011, Jayapura.

Badan Pusat Statistik Kabupaten Merauke, Merauke Dalam Angka 2006, Merauke.

Badan Pusat Statistik Kabupaten Merauke, Merauke Dalam Angka 2007, Merauke.

Badan Pusat Statistik Kabupaten Merauke, Merauke Dalam Angka 2008, Merauke.

Badan Pusat Statistik Kabupaten Merauke, Merauke Dalam Angka 2009, Merauke.

Badan Pusat Statistik Kabupaten Merauke, Merauke Dalam Angka 2010, Merauke.

Deddy Rustiono, 2008, Analisis Pengaruh Investasi, Tenaga Kerja, dan Pengeluaran Pemerintah Terhadap Pertumbuhan Ekonomi di Propinsi Jawa Tengah, Tesis Tidak Dipublikasikan, UNDIP, Semarang.

Efi Herawati, 2008, Analisis Pengaruh Faktor Produksi Modal, Bahan Baku, Tenaga Kerja dan Mesin Terhadap Produksi Glycerine Pada PT. Flora Sawita Chemindo Medan, Tesis Tidak Dipublikasikan, USU, Medan.

Heru Setiyadi, 2008, Penyerapan Tenaga Kerja Pada Industri Kecil Konveksi, Tesis Tidak Dipublikasikan, UNDIP, Semarang. 
Joesron dan Fathorozi, 2003, Teori Ekonomi Mikro Edisi I, Jakarta, Salemba Empat.

Jogiyanto Hartono, 2004, Teori Ekonomi Mikro Analisis Matematis, Penerbit Andi, Yogyakarta. Joko Sulistyo, 2010, Buku Latihan SPSS Statistik Parametrik, Cakrawala, Jakarta.

Miller dan Meiners, 1997, Teori Ekonomi Mikro Intermediate, Cetakan Ketiga Rajawali , Jakarta.

Mudrajat Kuncoro, 1997, Ekonomi Pembangunan (Teori dan Kebijakan), YKPN, Yogyakarta

Sadono Sukirno, 2005, Mikro Ekonomi, Teori Pengantar Edisi Ketiga, PT, Raja Grafindo Persada, Jakarta.

Sukartawi, 1991, Teori Ekonomi Produksi Dengan Pokok Bahasan Analisis Fungsi Cobb Douglas, Cetakan Ketiga Rajawali , Jakarta.

Sudarsono, dkk, 2000, Ekonomi Sumber Daya Manusia, Universitas Terbuka, Jakarta.

Sugiyono, 2003, Metode Penelitian Bisnis, Alfabeta , Bandung.

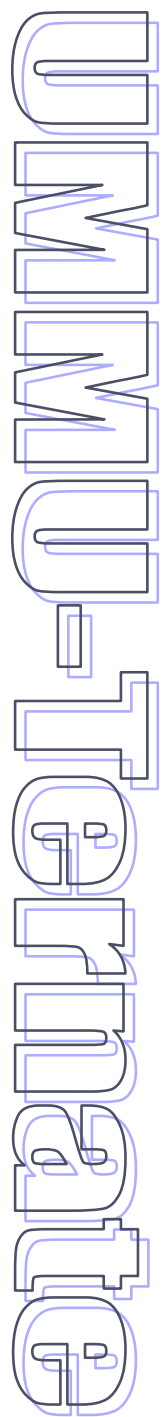

